\title{
EDYTA GAPSKA
}

Katolicki Uniwersytet Lubelski Jan Pawła II

\section{KONKURENCYJNOŚĆ POWÓDZTW Z ART. 189 K.P.C. I ART. 10 U.K.W.H. (UWAGI NA TLE WYROKU SĄDU NAJWYŻSZEGO Z 23 MARCA 2018 R. ${ }^{1}$ )}

\section{ISTOTA I CEL POWÓDZTWA O USUNIĘCIE NIEZGODNOŚCI W KSIĘDZE WIECZYSTEJ Z ART. 10 U.K.W.H. ORAZ POWÓDZTWA O USTALENIE Z ART. 189 K.P.C.}

Relacja pomiędzy powództwem o usunięcie niezgodności pomiędzy treścią księgi wieczystej a rzeczywistym stanem prawnym dochodzonym w trybie art. 10 u.k.w.h. i powództwem o ustalenie prawa (podlegającego ujawnieniu w księdze wieczystej) wytoczonym w oparciu o art. 189 k.p.c. pozostaje przedmiotem ciągłych kontrowersji zarówno w orzecznictwie, jak i w wypowiedziach przedstawicieli nauki ${ }^{2}$. Poza sporem pozostaje fakt, że celem tego pierwszego jest zawsze korekta wpisu w księdze

$1 \quad$ II CSK 371/17, «Lex» nr 2518847.

2 W tytule opracowania relację tę określono mianem konkurencyjności, który to termin pozwala uniknąć posługiwania się użytym przez Sąd Najwyższy, a kwestionowanym w dalszej części artykułu określeniem „zbieg roszczeń w zakresie powództw”. Równocześnie nawiązuje on do - sięgającej prawa rzymskiego - problematyki concursus actionum (a więc konkurencji czy też zbiegu skarg), a przy tym oddaje istotę analizowanego problemu sprowadzającego się do przesądzenia tego, czy wymienione w tytule powództwa mogą „konkurować ze sobą” o zaspokojenie tego samego interesu prawnego powoda. 
wieczystej poprzez przesądzenie o istnieniu i zakresie przysługującego uprawnionemu prawa podlegającego ujawnieniu w tej księdze ${ }^{3}$; z kolei powództwo o ustalenie jest $\mathrm{z}$ reguły ukierunkowane na osiągnięcie ogólniejszego, czy też - właściwiej - odmiennego celu wynikającego z potrzeby usunięcia istniejącej pomiędzy stronami sporu niepewności co do obecnego lub nawet przyszłego stosunku prawnego lub prawa (np. ważności umowy przenoszącej własność ${ }^{4}$ ), a więc oddziałującego nie tyle w aspekcie prawnorzeczowym, co raczej w ujmowanym wielopłaszczyznowo aspekcie skutków cywilnoprawnych ${ }^{5}$. Ponadto - w przeciwieństwie do tego pierwszego, które wytoczone może być wyłącznie przez osobę wymienioną w art. 10 ust. 1 u.k.w.h. - powództwo o ustalenie nie jest ograniczone w zakresie legitymacji czynnej inaczej niż tylko przez warunek posiadania interesu prawnego ${ }^{6}$, a równocześnie - jak przyjmuje

\footnotetext{
3 Wyrok SN z 10 sierpnia 2017 r., I CSK 12/17, «Lex» nr 2365544.

4 W tym przypadku zakres kognicji sądu rozpoznającego powództwo o ustalenie jawi się wręcz jako węższy niż w przypadku powództwa z art. 10 u.k.w.h., na co zwraca uwagę J. Kuropatwiński, Powództwo o uzgodnienie stanu prawnego ujawnionego $w$ księdze wieczystej. Glosa do wyroku Sądu Najwyższego z 9 lutego 2012 r. (III CSK 181/11), «Przegląd Sądowy»1/2013, s. 117.

5 Tak SN w uzasadnieniu wyroku z 23 marca $2018 \mathrm{r}$.

6 J. Kuropatwiński, op. cit., s. 116. Inna rzecz, że istnienie interesu prawnego w ustaleniu jest co do zasady negowane, jeżeli nieruchomość ma urządzoną księgę wieczystą i możliwe jest wytoczenie powództwa „o uzgodnienie”. Por. np. wyroki SN z 25 października 2002 r., IV CKN 1425/00, «Lex» nr 512008; z 5 grudnia 2002 r., III CKN 943/99, «OSNC» 3/2004, poz. 48; z 27 sierpnia 2008 r., II CSK 105/08, «Lex» nr 465897; z 16 lutego 2011 r., I CSK 305/10, «Lex» nr 798231, oraz z 4 marca 2011 r., I CSK 351/10, «Lex» nr 785272; por. ponadto J. IgNATOWICZ, J. WASILKowski, [w:] System prawa cywilnego, II, Własność i inne prawa rzeczowe, red. J. Ignatowicz, Wrocław 1977, s. 911. Istnieją jednak stosunkowo liczne sytuacje, gdy pomimo tego, że nieruchomość ma urządzoną księgę wieczystą, potrzebę ochrony sfery prawnej powoda będzie zaspokajało w sposób pełny, wystarczający i najbardziej adekwatny powództwo o ustalenie. Może to mieć miejsce np. wówczas, gdy powód zmierza właśnie do uniemożliwienia dokonania w księdze wieczystej korekty wpisu prawa własności mającej nastąpić np. w oparciu o umowę (sprzedaży, darowizny), której zarzuca nieważność (por. wyroki SN z 5 grudnia 2002 r., III CKN 943/99, «OSNC» 3/2004, poz. 48, i z 27 października 2005 r., III CK 106/05, «Lex» nr 371797), albo też w oparciu o kwestionowane przezeń przejście prawa własności z mocy samego prawa (wyroki SN z 1 grudnia 2004 r., III CK 50/04, «Lex» nr 512053, i z 24 sierpnia 2011 r., IV CSK 602/10, «Lex» nr 1111024).
} 
się w znacznej części wypowiedzi - co do zasady nie może stanowić podstawy wpisu do księgi wieczystej’. Ta ostatnia kwestia pozostaje jednak wciąż dyskusyjna ${ }^{8}$ i coraz wyraźniej wybrzmiewają opinie wskazujące

7 A. OleszKo, Wyrok sądowy jako podstawa wpisu do księgi wieczystej, «Przegląd Sądowy» 5/1993, s. 61; S. RudNICKI, Glosa do postanowienia SN z 25 sierpnia 2011 r., II CSK 665/10, «OSP» 3/2012, poz. 31; J. Kuropatwiński, op. cit., s. 117-118. Takie stanowisko zajął jednoznacznie SN np. w uchwałach z 16 grudnia 2009 r. (III CZP 80/09, «Lex» nr 531134) i z 18 maja 2010 r. (III CZP 134/09, «Lex» nr 577301), w których stwierdził, że wytoczenie powództwa o usunięcie niezgodności stanu prawnego ujawnionego w księdze wieczystej z rzeczywistym stanem prawnym nieruchomości (art. 10 u.k.w.h.) jest wyłącznym sposobem doprowadzenia do zgodności stanu prawnego ujawnionego w księdze z rzeczywistym stanem prawnym. Por. także wyrok SN z 27 października 2005 r., III CK 106/05, «Lex» nr 371797; uchwała SN z 13 stycznia 2011 r., III CZP 123/10, «OSNC» 9/2011, poz. 96 oraz wyrok SN z 16 lutego 2011 r., I CSK 305/10, «Lex» nr 798231, w którym przyjęto, że wyrok wydany w sprawie wniesionej na podstawie art. 189 k.p.c., nie mogąc stanowić podstawy wpisu (wykreślenia) w księdze wieczystej, mógłby stanowić wyłącznie podstawę do wytoczenia powództwa o uzgodnienie treści księgi wieczystej w oparciu o art. 10 u.k.w.h. i dowód w tej sprawie. Por. także postanowienia SN z 19 lipca 2006 r., I CSK 151/06, «Lex» nr 1170208, i z 22 lutego 2007 r., III CSK 344/06, «OSNC» 1/2008, poz. 12, oraz wyroki SN z 4 marca 2001 r., I CSK 340/10, «Lex» nr 785271; z 20 października 2011 r., IV CSK 13/11, «Lex» nr 1111005, i z 18 października 2012 r., II CSK 80/12, «Lex» nr 1619144.

8 Czego dowodzą np. orzeczenia SN (postanowienie SN z 25 sierpnia 2011 r., II CSK 665/10, «OSP» 3/2012, poz. 31 oraz wyrok SN z 20 października 2011 r., IV CSK 13/11, «Lex» nr 1111005), w których przyjęto, że wyrok sądu stwierdzający nieważność umowy, na podstawie której ujawniono w księdze wieczystej prawo własności nieruchomości, jest orzeczeniem wykazującym niezgodność, o której mowa w art. 31 ust. 2 u.k.w.h., i może stanowić podstawę wpisu potrzebnego do usunięcia niezgodności między treścią księgi wieczystej a rzeczywistym stanem prawnym nieruchomości. Także w uchwale z 14 marca 2014 r. (III CZP 121/13, «Lex» nr 1511150) SN wyraźnie i bezwarunkowo przyjął, że wyrok ustalający jako taki może być podstawą wpisu w księdze wieczystej. Analogiczne stanowisko prezentowane było także wcześniej; już w orzeczeniu z 17 czerwca 1960 r. (3 CR 328/60, «OSPiKA»6/1961, poz. 162) SN argumentował, że „nigdzie nie została wyrażona zasada, że dowód przeciwko treści wpisu może być przeprowadzony tylko w postępowaniu o uzgodnienie stanu prawnego ujawnionego w księdze wieczystej z rzeczywistym stanem prawnym. Domniemanie z art. 3 ust. 1 u.k.w.h. można obalić w każdym postępowaniu, w oparciu o wszelkie dostępne środki dowodowe”. Podobny pogląd zaprezentowano np. w uchwale SN z 26 marca 1993 r., III CZP 14/93, «OSNCP» 11/1993, poz. 196; w wyroku SN z 6 grudnia 2000 r., III CKN 179/99, «Lex» nr 51805; w wyroku SN z 6 czerwca 2007 r., III CSK 
na potrzebę elastycznego podejścia uwzględniającego w szczególności sytuację prawną stron i treść art. 31 ust. 2 u.k.w.h., który zezwala na dokonanie wpisu potrzebnego do usunięcia niezgodności między treścią księgi wieczystej a rzeczywistym stanem prawnym na podstawie jakiegokolwiek orzeczenia sądu wykazującego niezgodność, a nie tylko na podstawie orzeczeń wydanych w postępowaniach „o uzgodnienie”. De lege lata niezgodność ta powinna więc wynikać z samej sentencji orzeczenia, a nie tylko z jego uzasadnienia przesłankowo wskazującego na niezgodność jako okoliczność decydującą jedynie o treści rozstrzygnięcia. To właśnie literalne brzmienie art. 31 ust. 2 u.k.w.h. powinno więc decydować o zakwalifikowaniu konkretnego orzeczenia (w tym np. wydanego na podstawie art. $618 \$ 1$ k.p.c. w zw. z art. 688 i art. 567 $\$ 3$ k.p.c. i „rozstrzygającego” spór o prawo własności) jako zdatnego do wykazania niezgodności. Obecnie coraz dobitniej prezentowane jest stanowisko, że przepis art. 31 ust. 2 u.k.w.h. dopuszcza usunięcie wadliwości wpisu bez potrzeby wszczynania postępowania z art. 10 u.k.w.h., tj. wyłącznie w oparciu o orzeczenie sądu lub późniejszy dokument odnoszący się do zdarzenia, które stanowiło materialnoprawną podstawę wpisu, o ile ustalenie stanu prawnego nieruchomości nie wymaga uwzględnienia innych, prawnie doniosłych okoliczności wykraczających poza te, które były przedmiotem oceny wyrażonej w tych dokumentach (jak np. wada oświadczenia woli, ocena możliwości zastosowania przepisów o rękojmi wiary publicznej ksiąg wieczystych), a których

407/06, «Lex» nr 347313, a także w wyroku TK z 21 lipca 2004 r., SK 57/03, «OTK-A» 7/2004, poz. 69, jak również w piśmiennictwie. Por. np. S. RUdNICKI, Ustawa o księgach wieczystych i hipotece. Przepisy o postepowaniu w sprawach wieczystoksiegowych. Komentarz, Warszawa 2010, s. 37-38; K. GoŁĘBIOwsKI, O domniemaniach związanych z wpisami w ksiegach wieczystych, ich obalaniu oraz konstytutywnym charakterze wpisu (część I), «Przegląd Sądowy»10/2014, s. 90; A. ZAwiszA, Wyrok ustalający nieważność czynności prawnej jako podstawa wpisu w księdze wieczystej, «Rejent» 26.1/2016, s. 114.

9 Takie stanowisko zaprezentował SN m.in. we wspomnianym w tytule wyroku z 23 marca 2018 r. (II CSK 371/17, «Lex» nr 2518847), przyjmując w kategoriach oczywistego założenia, że niezgodność wpisu w księdze wieczystej z rzeczywistym stanem prawnym może być usunięta również na podstawie wyroku stwierdzającego nieważność umowy. 
uwzględnienie w postępowaniu wieczystoksięgowym jest wyłączone z uwagi na ograniczoną kognicję sądu (art. $626^{6} \$ 1$ i 2 k.p.c.) ${ }^{10}$.

10 Por. np. postanowienie SN z 21 czerwca 2012 r., II CSK 552/11, «Lex» nr 1293730. Równocześnie jednak interpretując znaczenie, jakie kryje się pod sformułowaniem: „Wykazanie niezgodności orzeczeniem sądu”, uwzględnić należy fakt, że zgodnie z art. 10 ust. 1 u.k.w.h. niezgodność może wynikać nie tylko z braku wpisu prawa, lecz także z wpisu obarczonego błędem (prawo wpisane błędnie lub prawo dotknięte wpisem nieistniejącego obciążenia lub ograniczenia), każdy zaś wpis (brak wpisu - w przeciwieństwie do wykreślenia wpisu - wpisem zaś nie jest; por. art. $628 \$ 6$ k.p.c.) korzysta z domniemania zgodności z rzeczywistym stanem prawnym (art. 3 u.k.w.h.). Dla obalenia tego domniemania (a konkretnie wniosku domniemania, a więc zgodności prawa ujawnionego z rzeczywistym stanem prawnym) zastrzeżona jest - jak się powszechnie przyjmuje - droga powództwa „o uzgodnienie” z art. 10 u.k.w.h. Prowadzi ono bowiem do obalenia istoty wniosku wynikającego z domniemania, a mianowicie do stwierdzenia, że stan prawny ujawniony w księdze wieczystej nie jest zgodny z rzeczywistym stanem prawnym i w konsekwencji jest podstawą do eliminacji z księgi wieczystej przesłanki domniemania (tj. błędnego wpisu), a więc zmiany treści wpisu (twierdząc odmiennie, a mianowicie, że „wyrok w sprawie o uzgodnienie treści księgi wieczystej z rzeczywistym stanem prawnym nie zmierza do „trwałego” obalenia domniemania prawnego ustanowionego w art. 3 u.k.w.h., lecz do eliminacji jego przesłanki” K. Gołębiowski sam jednak dostrzega, że eliminacja przesłanki domniemania z art. 3 u.k.w.h., a więc zmiana treści księgi wieczystej, jest jedynie skutkiem wyroku; por. K. GoŁĘBIOWSKI, op. cit., s. 88). De lege lata oznaczałoby to, że dla usunięcia niezgodności wynikającej z błędnego wpisu (bez względu na konstytutywny lub deklaratywny charakter wpisu) konieczne jest orzeczenie uzyskane w postępowaniu wszczętym na podstawie art. 10 u.k.w.h., w pozostałych sytuacjach (a więc gdy niezgodność nie wynika z wpisu, lecz z jego braku) wystarczające jest jakiekolwiek orzeczenie sądu lub inny dokument zdolny do wykazania niezgodności. Przepis art. 31 ust. 2 u.k.w.h., jako pozwalający na dokonanie zmiany wpisu bezpośrednio w postępowaniu wieczystoksięgowym, dotyczy jednak ze swej istoty spraw bezspornych, tj. gdy uczestnicy postępowania są zgodni co do wadliwości wpisu lub gdy spór pomiędzy nimi co do tej kwestii został już rozstrzygnięty w innym postępowaniu toczącym się z ich udziałem (bądź też z udziałem ich poprzedników prawnych). Por. P. PoDleś, Uwagi na temat relacji pomiędzy postępowaniem wieczystoksięgowym i postępowaniem o usunięcie niezgodności między stanem prawnym nieruchomości ujawnionym w księdze wieczystej a rzeczywistym stanem prawnym, «Przegląd Sądowy» 5/2011, s. 23-24. Nie rozwiewa on natomiast jednoznacznie wątpliwości co do tego, jakie postępowanie jest właściwe dla rozstrzygnięcia owego sporu. W tej mierze należy uwzględnić cele, przesłanki (zwłaszcza w przypadku powództwa o ustalenie z art. 189 k.p.c.) oraz uregulowania proceduralne dotyczące poszczególnych rodzajów postępowań. 
Do relacji pomiędzy powództwem dochodzonym w trybie art. 10 u.k.w.h. i powództwem o ustalenie prawa lub stosunku prawnego wytoczonym w oparciu o art. 189 k.p.c. Sąd Najwyższy odniósł się po raz kolejny we wspomnianym w tytule wyroku z 23 marca 2018 r., stwierdzając, że w sytuacji, gdy powództwo z art. 10 u.k.w.h. w całości zaspokaja interes powoda, dochodzi do „zbiegu roszczeń w zakresie powództw z art. 10 u.k.w.h. i art. 189 k.p.c.”. Równocześnie Sąd wyjaśnił, że sama możliwość żądania uzgodnienia treści księgi wieczystej z rzeczywistym stanem prawnym nie oznacza automatycznie braku interesu prawnego powoda, bo powództwo oparte na art. 189 k.p.c. służy udzieleniu ochrony również w zakresie innych skutków prawnych mogących wyniknąć ze stosunku, który powód kwestionuje i które może usunąć wyrok ex tunc.

Cytowane stanowisko zasługuje na szczególną uwagę nie tylko ze względu na zasadniczą dla rozstrzygnięcia sprawy konstatację - nota bene wpisującą się w liberalne podejście do pojęcia interesu prawnego w ustaleniu w rozumieniu art. 189 k.p.c. - zakładającą, że interesu tego nie wyklucza możliwość zgłoszenia przez powoda roszczenia z art. 10 u.k.w.h., ale i z uwagi na zaprezentowany niejako akcesoryjnie pogląd o możliwym „zbiegu roszczeń” w zakresie wymienionych powództw. To dalszoplanowe stwierdzenie, pomimo że mające jedynie dopełniające znaczenie w argumentacji Sądu, zasługuje na bardziej wnikliwą analizę.

\section{Stanowisko Sądu Najwyższego o konkurenCyjności POWÓDZTW Z ART. 189 K.P.C. I ART. 10 U.K.W.H.}

Pomimo istniejącej niewątpliwie relacyjności pomiędzy powództwami $z$ art. 10 u.k.w.h. i art. 189 k.p.c. i wydanymi w ich wyniku orzeczeniami odmienność celów każdego z nich jest oczywista. W konsekwencji trudno odmówić słuszności twierdzeniu, że powód nie traci interesu w ustaleniu, jeżeli ochrona jego sfery prawnej wymaga wykazania, że stosunek prawny nie istnieje, a więc wyrok w sprawie o świadczenie lub uzgodnienie treści księgi wieczystej z rzeczywistym stanem prawnym nie usunie niepewności w zakresie wszystkich skutków prawnych mogących wynikać z tego stosunku w przyszłości, co ma miejsce zwłaszcza 
w przypadku nieważności umowy. Na pełną aprobatę zasługuje także wniosek, że uzależnienie powództwa o ustalenie od interesu prawnego należy pojmować elastycznie, z uwzględnieniem jego celowościowej wykładni, szeroko pojmowanego dostępu do sądów w celu zapewnienia należytej ochrony prawnej i konkretnych okoliczności danej sprawy. Niemniej wybór właściwszego roszczenia procesowego, a więc tego, które prowadzi do uzyskania adekwatnego w danym stanie rodzaju ochrony prawnej, nie jest już - jak pokazuje praktyka orzecznicza - tak oczywisty, zwłaszcza gdy uwzględni się rozbieżności w kwalifikowaniu interesu prawnego w ustaleniu stanu prawnego nieruchomości czy nie tak rzadkie przypadki kwestionowania przez sąd wieczystoksięgowy podstawy wpisu w postaci orzeczenia wydanego na podstawie art. 189 k.p.c. W każdym razie wybór powództwa zależy zawsze od powoda ${ }^{11}$, który zgłaszając konkretne żądanie daje wyraz temu, jakiego rodzaju ochrony prawnej oczekuje, a więc jaki rodzaj ochrony zaspokaja jego potrzebę prawną. W tym miejscu ujawnia się kreujące znaczenie żądania udzielenia ochrony prawnej określonej co do treści, rodzaju i formy, mającej w przekonaniu powoda stanowić korzyść zaspokajającą jego ogólnie pojmowaną potrzebę prawną. W takim właśnie znaczeniu dążenie do uzyskania ochrony prawnej stanowi niematerialny element współkreujący roszczenie procesowe i pozwalający na jego identyfikację. Choć tak rozumiany, generalny warunek poszukiwania ochrony prawnej nie został w polskim systemie prawa procesowego wyraźnie normatywnie wyartykułowany ${ }^{12}$, to jednak w literaturze przedmiotu jest powszechnie

11 Jak wskazał SN w uchwale z 14 marca 2014 r. (III CZP 121/13, «OSNC» 2/2015, poz. 15) i powtórzył m.in. w wyroku z 23 marca 2018 r., „o wyborze efektywnego z punktu widzenia zamierzonych celów środka ochrony prawnej decyduje wyłącznie zainteresowany; ocena, czy i jaki użytek uczyni on z uzyskanego orzeczenia w przyszłości, nie jest objęta kognicją sądu”.

12 Na wzór np. art. 100 włoskiego kodeksu postępowania cywilnego z 1940 r. (dla którego pierwowzorem był art. 36 kodeksu z 1865 r. wywodzący się jeszcze z francuskiej tradycji doktrynalnej i orzeczniczej), zgodnie z którym do wniesienia powództwa i podjęcia obrony przeciwko niemu konieczne jest posiadanie interesu (Interesse ad agire). Interes ten uznawany jest za przesłankę dopuszczalności każdego powództwa i wyraża się w istnieniu konkretnego i aktualnego - przynajmniej na moment orzekania - związku pomiędzy naruszeniem (zagrożeniem) prawa i wnioskowanym 
wskazywany jako zasadniczy element powództwa stanowiący konieczny aspekt żądania i wyrażający jego istotę ${ }^{13}$.

środkiem ochrony prawnej, której nie można uzyskać inaczej niż tylko na drodze sądowej (C.Cass., 13 aprile 2011, n. 8464; C.Cass., 26 maggio 2008, n. 13556; C.Cass., 17 maggio 2006, n. 11536; podobnie G. Chiovenda, cyt. za: G. Monteleone, Scritti sul processo civile, I: Teoria generale del processo - Disposizioni generali, Roma 2012, s. 43). We włoskiej nauce prawa przesłanka ta traktowana jest jako fundamentalna dla całego postępowania (por. np. F. CARnelutti, Sistema di diritto processuale civile, I: Funzione e composizione del processo, Padova 1936, s. 5 i n.), jakkolwiek jej znaczenie miało pierwotnie uzasadnienie praktyczne. Podobna, choć nie tak wyrazista reguła podporządkowująca proces cywilny interesowi prawnemu (intérêt a agir) wynika np. $\mathrm{z}$ art. 31 francuskiego kodeksu postępowania cywilnego z 1975 r., zgodnie z którym powództwo jest „otwarte” dla wszystkich, którzy mają uzasadniony interes (un intérêt légitime) w powodzeniu lub odrzuceniu żądania, jak również z art. 17 belgijskiego kodeksu sądowego, z którego to przepisu wynika, że nie jest dozwolone kierowanie skargi (żądania), jeżeli powód nie ma legitymacji (qualité) i interesu (intérêt), by je formułować. Interes ten powinien wyrażać się w rzeczywistej, istniejącej i aktualnej korzyści (l'intérêt doit être né et actuel), jaką rozstrzygnięcie ma przynieść jednostce poszukującej ochrony sądowej. Por. P. RYLSKI, K. Weitz, Intérét, interesse ad impugnare, Beschwer, aggrievance, [w:] Oblicza prawa cywilnego. Ksiega jubileuszowa dedykowana Profesorowi Janowi Błeszyńskiemu, red. K. SzczePAnowsKA-KozŁowsKA, Warszawa 2013, s. 593. Szerzej o znaczeniu pojęcia interesu w doktrynie belgijskiej por. Ł. BŁAszczak, Znaczenie interesu prawnego w poszukiwaniu ochrony prawnej w procesie cywilnym na przykładzie poszczególnych rodzajów powództw, [w:] 'Ius est a iustitia appellatum'. Księga jubileuszowa dedykowana Profesorowi Tadeuszowi Wiśniewskiemu, red. T. Ereciński, J. Gudowski, M. Pazdan, red. nauk. M. Tomalak, Warszawa 2017, s. 42-43.

13 Por. np. M. WAligórski, Kumulacja roszczeń w procesie, «Polski Proces Cywilny» 18-19/1937, s. 556 (stwierdza on, że żądanie zawiera wniosek o udzielenie twierdzeniu prawnemu ochrony prawnej); H. Trammer, Następcza bezprzedmiotowość procesu cywilnego, Kraków 1950, s. 5 (który za element powództwa uznaje wniosek o udzielenie ochrony sądowej); W. Broniewicz, Przyczyny oddalenia powództwa, «PiP» 19.5-6/1964, s. 832 (według którego wytoczenie powództwa polega na wystąpieniu do sądu $\mathrm{z}$ twierdzeniem o istnieniu normy prawnej w celu uzyskania ochrony prawnej polegającej na wiążącym ustaleniu istnienia lub nieistnienia tej normy); Z. REsıCH, 'Res iudicata', Warszawa 1978, s. 32 (podobnie jak E. Waśkowski, uznaje on wniosek o udzielenie ochrony prawnej za element treści powództwa), czy W. BERUTOWICz, Znaczenie prawne sądowego dochodzenia roszczeń, Warszawa 1966, s. 84-85, 117-118 (który podkreśla „zasadnicze znaczenie” dokładnego określenia żądania wraz z przytoczeniem okoliczności faktycznych dla uznania pisma za pozew, a w konsekwencji dla 
W wyroku Sądu Najwyższego z 23 marca 2018 r., poza godnym aprobaty poglądem o odmienności celów i istoty ochrony prawnej udzielanej w uwzględnieniu wyżej wymienionych powództw, szczególną uwagę zwraca teza zakładająca występowanie swoistej konkurencyjności tych powództw. Przyjęto mianowicie, że powództwo o usunięcie niezgodności w treści księgi wieczystej może w całości zaspokajać interes powoda uzasadniający wytoczenie powództwa $z$ art. 189 k.p.c. Ma to mieć miejsce wówczas, gdy powództwo oparte na art. 189 k.p.c. nie służyłoby udzieleniu ochrony w zakresie innych skutków prawnych niż te, które powstają na skutek wyroku ustalającego niezgodność treści księgi wieczystej. W takim przypadku, zdaniem Sądu, dochodzi do „zbiegu roszczeń w zakresie powództw z art. 10 u.k.w.h. i art. 189 k.p.c.”.

Głębsza analiza powyższej kwestii pozwala jednak twierdzić, że pomiędzy oboma tymi roszczeniami procesowymi - między innymi z uwagi na odmienne cele i przesłanki, a przede wszystkim odmienny zakres ochrony prawnej - nie zachodzi całkowita konkurencyjność czy też alternacja (a więc dowolność wyboru jednego z nich) ${ }^{14}$ - pozwalająca na uznanie, że w sytuacji, gdy „powództwo z art. 10 u.k.w.h. w całości zaspokaja interes prawny powoda”, mamy do czynienia ze „zbiegiem

określenia granic przedmiotowych procesu oraz skutków przedmiotowych dochodzenia roszczeń w zakresie prawa materialnego). Ten ostatni wskazuje ponadto wyraźnie, że na przedmiot konkretnej sprawy cywilnej składa się - poza przedmiotem badania i ustalania oraz przedmiotem rozstrzygnięcia - także przedmiot ochrony prawnej udzielanej przez wydanie orzeczenia sądowego (W. Berutowicz, Postępowanie cywilne $w$ zarysie, Warszawa 1974, s. 130, 135-136).

14 Tak też J.D. SŁupıK, Powództwo o ustalenie istnienia lub nieistnienia stosunku prawnego lub prawa (art. 189 k.p.c.) a powództwo o uzgodnienie treści księgi wieczystej z rzeczywistym stanem prawnym (art. 10 ust. 1 u.k.w.h.), «Rejent» 24.7/2014, s. 97 i n. Autorka jednoznacznie nie zgadza się z twierdzeniem, że art. 189 k.p.c. to „substytut” regulacji z art. 10 ust. 1 u.k.w.h., wskazując przy tym, że samo orzeczenie przesądzające o nieważności podstawy wpisu nie rodzi ex lege skutku w postaci zmiany wpisu w księdze wieczystej tak, ażeby wpis ten odpowiadał rzeczywistym stosunkom własnościowym. Powyższe prowadzi autorkę do wniosku, że nie jest dopuszczalne zamienne stosowanie $\mathrm{w}$ danym stanie faktycznym powództw $\mathrm{z}$ art. 10 ust. 1 u.k.w.h. i z art. 189 k.p.c., a wytoczenie powództwa o uzgodnienie treści księgi wieczystej z rzeczywistym stanem prawnym wyklucza wystąpienie przez powoda $z$ roszczeniem $z$ art. 189 k.p.c. w tej samej sprawie. 
roszczeń w zakresie powództw z art. 10 u.k.w.h. i art. 189 k.p.c.”, co - jak należy doprecyzować - miałoby prowadzić do negatywnej weryfikacji interesu prawnego w ustaleniu, a tym samym skutkowałoby odmową uwzględnienia powództwa $\mathrm{z}$ art. 189 k.p.c. Ze stanowiskiem tym w zakresie, w jakim uznaje wspomnianą sytuację za „zbieg roszczeń w zakresie powództw”, nie można się w pełni zgodzić, nawet jeżeli uwzględni się cel argumentacyjny przyświecający Sądowi Najwyższemu, który w dalszej części cytowanego judykatu skonstatował, że wymieniona sytuacja - jako wyjątkowa - nie pozwala na automatyczne odmawianie powodowi interesu prawnego w ustaleniu $\mathrm{z}$ uwagi na samą możliwość żądania uzgodnienia treści księgi wieczystej z rzeczywistym stanem prawnym ${ }^{15}$. Pewne zastrzeżenia budzi w szczególności posłużenie się przez Sąd Najwyższy nie w pełni precyzyjnie wykorzystanym, a zaczerpniętym z prawa materialnego wyrażeniem „zbieg roszczeń" uzupełnionym stwierdzeniem: „w zakresie powództw” nadającym mu treść procesową. Tym samym niejednoznaczne są intencje towarzyszące posłużeniu się tym określeniem, a w szczególności to, czy zostało ono użyte w takim znaczeniu, jakie przypisuje mu się na gruncie nauki prawa cywilnego materialnego, czy też - co sugerowałoby dopełnienie: „w zakresie powództw” - sąd przyjął swoistą konstrukcję zbiegu roszczeń procesowych ${ }^{16}$. Każda $\mathrm{z}$ tych opcji budzi zastrzeżenia. Nie można także zaaprobować założenia, że powództwo z art. 10 u.k.w.h.

15 W tym zakresie SN podzielił argumentację przyjętą w uchwale z 15 marca $2006 \mathrm{r}$. (III CZP 106/05, «OSN» 10/2006, poz. 160), zgodnie z którą orzeczenie, którego podstawę stanowi art. 10 u.k.w.h., realizuje odrębną kategorię roszczeń procesowych zbliżonych do powództw kształtujących. Stanowisko to SN zaaprobował także m.in. w uchwale z 14 marca 2014 r. (III CZP 121/13, «OSNC» 2/2015, poz. 15), w której uzasadnieniu wskazano, że powództwo o ustalenie i powództwo o usunięcie niezgodności nie mają tego samego charakteru, lecz stanowią dwa niezależne środki ochrony prawnej, oparte na odmiennych przesłankach i zmierzające do osiągnięcia innego celu. Dochodzi więc do zbiegu roszczeń, mającego charakter konkurencyjny jedynie wtedy, gdyby powództwo o usunięcie niezgodności zaspokajało w całości interes prawny powoda.

16 W piśmiennictwie procesowym istotnie można spotkać określenie: „zbieg powództw”. Por. np. J. Mucha, Zawisłość sprawy w procesie cywilnym, Warszawa 2014, s. 307. 
jest $\mathrm{w}$ stanie zaspokoić ten sam interes prawny, który uzasadniałby wytoczenie powództwa $\mathrm{z}$ art. 189 k.p.c.

3. „ZBIEg ROSZCZEŃ W ZAKRESIE POWÓDZTW Z ART. 10 U.K.W.H. I ART. 189 K.P.C." W KONTEKŚCIE MATERIALNOPRAWNYCH ZAŁOŻEŃ ZBIEGU ROSZCZEŃ

W pierwszej kolejności wyjaśnić należy, że kategoria zbiegu roszczeń materialnoprawnych (Anspruchskonkurrenz) nie jest jednoznaczna i pomimo bogatej literatury przedmiotu trudno przyjacć, aby istniała jedna, powszechnie akceptowana definicja tego zjawiska. W języku prawnym zbieg, którego istota jest wciąż dyskusyjna i różnie postrzegana, polega co do zasady na tym, że jeden i ten sam stan faktyczny „staje się hipotezą dla większej liczby dyspozycji”', a tym samym „aktywuje” wiele skutków prawnych przewidzianych w dyspozycjach większej liczby norm. Taka charakterystyka nie wyczerpuje jednak wszystkich istotnych elementów pojęcia zbiegu, w tym nie rozstrzyga, czy o jego zaistnieniu przesądza sama już abstrakcyjna, hipotetyczna możliwość zastosowania wielu norm prowadząca do mnogości potencjalnych kwalifikacji prawnych tego samego zdarzenia pomimo tego, że w rzeczywistości istnieją reguły wyłączające skutki zbiegu, a w konsekwencji zbieg - jako tylko hipotetyczny - ma charakter pozorny (rzekomy) i z uwagi na komplementarno-korekcyjny charakter zależności między zbiegającymi się normami ${ }^{18}$ może być wyeliminowany poprzez ustalenie, które normy w danym przypadku są zbędne ${ }^{19}$, czy też wyłącznie wówczas, gdy

\footnotetext{
17 E. ŁęTOWsкA, Zbieg norm w prawie cywilnym, Warszawa 2002, s. 2.

18 Tak określa je E. ŁęTowska, op. cit., s. 53, a w ślad za nią także S. CIEślak, Powiązania wewnątrzsystemowe w postępowaniu cywilnym, Warszawa 2013, s. 113.

19 Jak wskazuje E. ŁĘTowska, cytując F. Bydlinskiego (op. cit., s. 13), pozorny zbieg norm jest „sztuką eliminacji tego, co zbędne przy rozwiązywaniu konkretnego wypadku, jest codziennością prawniczej pracy”. Dalej autorka twierdzi, że „usuwanie pozornego zbiegu norm, czyli eliminowanie potencjalnej wielości ocen w dążeniu do prawidłowego zastosowania prawa jest sprawą zasad i technik metodyki prawniczej, poprawnej wykładni [...], a także problematyki norm kumulowanych [...] i alternatywnych [...]".
} 
na skutek braku norm kolizyjnych wynikających czy to z wyraźnego przepisu ustawy, czy to z reguł wykładni pozwalających na wskazanie wzajemnego stosunku norm można w konkretnym stanie powoływać się jednocześnie na wszystkie powiązane formalnokolizyjnie normy ${ }^{20} \mathrm{i}$ zastosować ich odmienne dyspozycje (zbieg taki nazywa się rzeczywistym lub realnym ${ }^{21}$. Opowiedzenie się za jednym z tych ujęć jest determinowane przez przyjęcie bądź to perspektywy osoby podejmującej dopiero próbę oceny prawnej danego stanu faktycznego (tzw. zbieg na wejściu) i włączającej w to zagadnienie całe spektrum problemów związanych $\mathrm{z}$,etapem dochodzenia do zastosowania prawa”, a więc ze sposobami poszukiwania - na etapie stosowania prawa ${ }^{22}$ - norm niezbędnych do redukowania wielu skutków prawnych jednego zdarzenia, bądź też osoby, która w celu eliminacji zbiegu dokonała już tego rodzaju oceny w drodze analizy normatywnej i przeprowadzonej wykładni, jednak nie znalazła reguły pozwalającej na wyłączenie wielości ocen, a w konsekwencji na zmarginalizowanie czy usunięcie zjawiska zbiegu (zbieg na wyjściu ${ }^{23}$. Wybór jednego z powyższych zapatrywań jest determinowany przez przyjętą konwencję badawczą uwarunkowaną określonym celem naukowym i tak samo jak nie jest generalną koniecznością w prawie cywilnym, tak samo, a nawet tym bardziej, nie warunkuje

\footnotetext{
20 E. ŁęTOWsKa, op. cit., s. 55-57; S. Cieślak, op. cit., s. 113.

21 S. Grzy bowski, Prawo cywilne. Zarys części ogólnej, Warszawa 1985, s. 132; IDEM, [w:] S. Grzybowski, J. SKĄPSKi, S. Wójcik, Zarys prawa cywilnego, Warszawa 1988, s. 72, a także E. ŁĘTOWsKA, op. cit., s. 12, która uznaje, że realny zbieg norm pozwalający na odmienne oceny prawne tego samego zdarzenia jest nie tylko zjawiskiem rzadkim, a przy tym uznawanym za usterkę legislacyjną, lecz także mniej interesującym i żywotnym z perspektywy badawczej.

22 E. Łętowska, op. cit., s. 26-27; E. ŁęTOwska, K. OsajdA, [w:] System Prawa Prywatnego. Prawo cywilne - część ogólna, I, red. M. SAfJan, Warszawa 2012, s. 574-575.

23 E. Łętowska, op. cit., s. 20-22. Pierwszą, szczególnie wartościową z punktu widzenia nauki prawa, perspektywę badawczą przyjmuje np. A. OHAnowicz (Zbieg norm w polskim prawie cywilnym, [w:] Alfred Ohanowicz. Wybór prac, wstęp Z. RADWAŃsKI, oprac. A. GuLCzyńsKi, Warszawa 2007, s. 175-176), z kolei w drugiej konwencji swoje rozważania utrzymuje S. Grzybowski, który traktuje zbieg norm jako anomalię wynikającą z błędu ustawodawcy lub badacza (S. Grzy Bowski, [w:] Zarys prawa cywilnego..., s. 125 i 131; podobnie Z. Ziembiński, Problematyka ogólna zbiegu przepisów prawnych, [w:] Studia zprawa zobowiązań, Warszawa-Poznań 1979, s. 345).
} 
wyników rozważań w dziedzinie prawa procesowego. Skoro bowiem w każdym przypadku zbiegu kwestia zastosowania tej czy innej normy prawnej albo też uwzględnienia żądania w oparciu o tak czy inaczej sformułowanie roszczenie jest zależna od sądu rozpoznającego sprawę i jego ustaleń w przedmiocie istnienia lub nieistnienia norm lub reguł wykładni wyłączających w konkretnym stanie skutki konkurencji, co - innymi słowy - oznacza, że w sądowym procesie decyzyjnym organ procesowy może zostać postawiony wobec zbiegu zarówno na wejściu (w momencie zgłoszenia żądania), jak i w punkcie wyjścia (w chwili orzekania), przeto przyjąć należy, że na gruncie prawa procesowego pozorny lub rzeczywisty charakter zbiegu ma drugorzędne znaczenie dla oceny skutków wyboru (zgłoszenia) określonego roszczenia procesowego. Dużo większe znaczenie dla oceny procesowych skutków zbiegu ma natomiast rozstrzygnięcie, czy jeden stan faktyczny (czy też ogólniej - pewna określona prawnie sytuacja) wyczerpuje hipotezy wielu norm ${ }^{24}$ o takich samych dyspozycjach ${ }^{25}$, czy też wynikające z nich skutki prawne są odmienne. Tożsamość dyspozycji w takich przypadkach będzie bowiem miała decydujące znaczenie pozwalające przyjąć, że wielość norm lub roszczeń materialnoprawnych uzasadnia jedynie konkurencyjność kwalifikacji prawnych tego samego żądania na gruncie procesowym $^{26}$. Zatem jeżeli miejsce zetknięcia się norm „uruchomionych" przez jedno zdarzenie, tj. ich element wspólny w całości będzie się pokrywał z ich dyspozycjami, wówczas procesowym refleksem stanie się jedno żądanie znajdujące mnogie uzasadnienie prawne, z kolei różność dyspozycji, obok tożsamości składników hipotez, stanowić może przesłankę formułowania wielu żądań, a z pewnością istnienia wielu roszczeń

24 Czy też - jak ujmuje to E. ŁęTowska (op. cit., s. 1) - staje się hipotezą wielu „norm jednostkowego zastosowania”.

${ }^{25}$ W takim przypadku założyć należy, że hipotezy norm pokrywają się ze sobą jedynie częściowo, zaś ten sam stan faktyczny zawiera w sobie elementy wyczerpujące wszystkie te hipotezy. Jak bowiem trafnie wskazuje A. OHANOwICZ, nie sposób racjonalnie zakładać istnienia w jednym systemie prawnym norm o całkowicie identycznych hipotezach i dyspozycjach (op. cit., s. 177, 180).

26 E. ŁęTOWSKA, op. cit., s. 1. 
materialnoprawnych ${ }^{27}$. Za różne uznaje się natomiast takie dyspozycje, które z jednym stanem faktycznym wyczerpującym jednocześnie hipotezy wielu norm prawnych wiążą całkowicie lub częściowo różne skutki prawne, w tym na przykład w zakresie przedmiotu świadczenia, sposobu dochodzenia, terminu przedawnienia czy rozkładu ciężaru dowodu ${ }^{28}$.

Przenosząc powyższe uwagi na grunt analizowanego problemu, można prima facie założyć, że stan faktyczny (np. nieważność czynności będącej podstawą wpisu prawa do księgi wieczystej) może spełniać wymóg tożsamości uzasadniającej zaistnienie wyżej wspomnianego zbiegu tylko w jednym przypadku, a mianowicie wówczas, gdy jedynym chronionym interesem prawnym powoda jest osiągnięcie zgodności treści księgi wieczystej z rzeczywistym stanem prawnym. Możliwość wytoczenia (uzasadnionego) powództwa z art. 189 k.p.c. wymaga bowiem dodatkowo istnienia usprawiedliwionej określonymi faktami niepewności (sporu) pomiędzy konkretnymi podmiotami (stronami postępowania) co do sytuacji prawnej powoda, której to niepewności nie da się usunąć w żadnym innym trybie. Brak tego rodzaju okoliczności faktycznych sprawiałby więc, że powództwo z art. 189 k.p.c. byłoby nieuzasadnione (z uwagi na możliwość uzyskania ochrony w trybie art. 10 u.k.w.h.). Równocześnie zaistnienie takich okoliczności i uczynienie ich koniecznymi składnikami podstawy faktycznej nie pozwala już mówić o tożsamości hipotez, a w konsekwencji o zbiegu roszczeń.

Niemniej istotna, a nawet rozstrzygająca pozostaje kwestia możliwości przyjęcia istnienia roszczenia w znaczeniu materialnoprawnym w przypadku żądania ustalenia prawa lub stosunku prawnego. Skoro bowiem roszczenie materialnoprawne (Anspruch) oznacza prawną możliwość domagania się od osób zobowiązanych, aby wykonały ciążące na nich obowiązki celem przywrócenia legalnego stanu faktycznego, a więc stanu odpowiadającego prawom podmiotowym ${ }^{29}$, przeto nie

27 A. Ohanowicz, op. cit., s. 180, 182.

28 Ibidem, s. 180-181.

29 E. WAśkowski, Powództwo i jego zmiana, «Polski Proces Cywilny» 3/1935, s. 67. Podobnie S. Grzy bowski, [w:] Zarys prawa cywilnego..., s. 65; IDEM, Prawo cywilne..., s. 113; IDEM, [w:] System prawa cywilnego, I: Część ogólna, red. nacz. W. CzACHóRsKI, red.S. Grzy bowski, Wrocław-Warszawa-Kraków-Gdańsk-Łódź 1985, s. 219; A. KLEIN, 
można przyjąć, aby roszczeniu procesowemu o ustalenie odpowiadało tak właśnie rozumiane roszczenie materialnoprawne ${ }^{30}$. To natomiast z góry wyłącza możliwość odnoszenia problematyki zbiegu roszczeń do sytuacji, w której jedno z żądań dotyczy właśnie ustalenia. Co więcej, zwolennicy poglądu, że żądanie z art. 10 u.k.w.h. jest rodzajem powództwa o ustalenie ${ }^{31}$, mogą odnosić powyższą uwagę do obu analizowanych żądań ${ }^{32}$. Jeżeli więc żadne z powództw wymienionych w art. 189 k.p.c. $\mathrm{i}$ art. 10 u.k.w.h. nie jest wywodzone $\mathrm{z}$ roszczenia materialnoprawnego rozumianego - raczej jednolicie - jako możność oczekiwania od drugiej strony określonego zachowania się, przeto w analizowanej sytuacji nie można mówić o dochodzeniu pozostających w zbiegu roszczeń materialnoprawnych ${ }^{33}$.

Elementy zobowiązaniowego stosunku prawnego, Wrocław 1964, s. 47 i n.; W. CzACHóRski, Zobowiązania. Zarys wykładu, Warszawa 1983, s. 40.

30 K. Korzan, Orzeczenia konstytutywne w postępowaniu cywilnym, Warszawa 1972, s. 145-146; W. Broniewicz, op. cit., s. 834; B. DobrZAŃski, Glosa do orzeczenia Sądu Najwyższego z dnia 9 lipca 1963 roku w sprawie o sygn. 3 PR 362/62, "OSPiKA» 11/1964, s. 466.

31 Tak np. SN w postanowieniu z 25 sierpnia 2011 r., II CSK 665/10, «Lex» nr 898696.

32 Pomimo tego decydującego w istocie argumentu wcześniejsze rozważania mają istotne znaczenie dla wykazania nieadekwatności zastosowania materialnoprawnej konstrukcji zbiegu roszczeń w odniesieniu do powództw z art. 189 k.p.c. i art. 10 u.k.w.h. Sytuację tę można by co najwyżej analizować w kategoriach zbiegu norm. Konieczność odrębnego traktowania zagadnienia zbiegu norm i zbiegu roszczeń wydaje się oczywista, choć i ta ostatnia kwestia obarczona jest trudnościami związanymi, po pierwsze, $z$ potrzebą uwzględnienia dorobku doktryny zbudowanego na pojęciu rzymskiej „actio” (skargi). To zaś powstało wprawdzie jeszcze przed pojawieniem się windscheidowskiego pojęcia „roszczenie”, niemniej wynikało z jednolicie, niepodzielnie wówczas pojmowanego porządku prawnego i łączyło w sobie pierwiastki zarówno procesowe, jak i materialne, niewyodrębniane przez ówczesne prawo, a determinujące współczesne definiowanie tego pojęcia. Dalsze trudności wynikają z funkcjonowania we współczesnej nauce prawa całkowicie odmiennych treściowo pojęć roszczenia w znaczeniu materialnoprawnym i procesowym.

33 Wniosek ten jawi się wyraziście na gruncie terminologii niemieckojęzycznej, gdzie dla roszczenia materialnoprawnego używa się sformułowania Anspruch, zaś określeniu elementów rzeczywistości procesowej służą takie pojęcia, jak: Antrag (wniosek, żądanie), a precyzyjniej Klageantrag oraz Klage (skarga, a w tłumaczeniu na terminologię polskiego kodeksu postępowania cywilnego - powództwo). Wykorzystanie 
4. Procesowy Kontekst „ZBIEgu RosZCZEŃ Z ART. 10 U.K.W.H. I ART. 189 K.P.C.”

Próba odczytania frazy: „zbieg roszczeń w zakresie powództw z art. 10 u.k.w.h. i art. 189 k.p.c.” w kontekście procesowym, a mianowicie przyjęcie, że rozchodzi się tu o zbieg roszczeń procesowych (żadne inne interpretacje nie wchodzą w rachubę, gdyż istnieją jedynie roszczenia materialnoprawne lub procesowe) - jakkolwiek najbardziej chyba zgodna z intencją Sądu Najwyższego ${ }^{34}$ - także nie prowadzi do satysfakcjonujących prawnie wniosków.

W pierwszej kolejności wskazać należy, że kategoria zbiegu, mająca jak wskazano powyżej - wyraźne źródła i znaczenie materialnoprawne, nie została transponowana na grunt nauki prawa procesowego, stąd też trudno przypisywać jej tu jakiekolwiek ugruntowane znaczenie.

Domniemywać należy, że w omawianym przypadku przez pojęcie zbiegu roszczeń w zakresie powództw Sąd Najwyższy rozumiał sytuację, gdy identyczną ochronę prawną - bo przecież „w całości zaspokajającą interes powoda" - można wyjątkowo uzyskać za pomocą odmiennych powództw, a więc roszczeń procesowych różniących się co do swych elementów konstrukcyjnych, przesłanek i celów, co więcej, mających wyraźnie odrębną regulację normatywną i wreszcie prowadzących do udzielenia innej co do charakteru i sposobu ochrony prawnej. Posłużenie się pojęciem interesu prawnego powoda i kontekst argumentacyjny wskazujący na relację między powództwem „o uzgodnienie” z art. 10

tych określeń pozwala na ukazanie z odmiennej perspektywy niż ta, która właściwa jest dla polskiego procesualisty dysponującego odmienną siatką pojęciową, istoty wielości lub identyczności przedmiotów postępowania (Streitgegenstands) przy równoczesnym pominięciu terminologicznie dyskretnych wprawdzie, acz teoretycznie doniosłych różnic pomiędzy znaczeniem pojęć: „powództwo” (Klage) i „roszczenie procesowe” (dla którego w nauce prawa niemieckiego używa się jedynie sformułowania prozessual Anspruch). W konsekwencji w prawie niemieckim zbieg roszczeń określany jest mianem Anspruchskonkurrenz, podczas gdy wielości powództw nie analizuje się w kategoriach zbiegu (konkurencji), lecz w ramach procesowego gromadzenia, łączenia (kumulacji) skarg. W odniesieniu do tego zjawiska używa się powszechnie pojęcia Klagenhäufung (lub Klagenverbindung).

34 Skoro nie można mówić o roszczeniu materialnoprawnym o ustalenie. 
u.k.w.h. i powództwem o ustalenie z art. 189 k.p.c. pozwala ponadto wnioskować, że Sąd Najwyższy próbował ustosunkować się do tych wyjątkowych sytuacji, w których interes prawny w ustaleniu w rozumieniu art. 189 k.p.c. sprowadza się do przesądzenia treści prawa lub stosunku prawnego podlegającego ujawnieniu w księdze wieczystej, a pozostającego $\mathrm{w}$ sprzeczności $\mathrm{z}$ prawem ujawnionym na dzień orzekania. Powyższa teza - nawet w realiach sprawy, na gruncie której została wyrażona - budzi jednak zastrzeżenia, bowiem zdaje się nie uwzględniać podstawowej z punktu widzenia potrzeby prawnej powoda kwestii, jaką jest charakter i sposób żądanej, a więc i możliwej do wyrażenia w orzeczeniu sądowym ochrony prawnej. W przypadku powództwa „o uzgodnienie” jest to bowiem usunięcie z księgi wieczystej niezgodności wynikającej z błędnie wpisanego lub niewpisanego prawa i powodującej, że treść księgi - na dzień orzekania - nie odpowiada rzeczywistemu stanowi prawnemu nieruchomości, a w konsekwencji ujawnienie w celu zapewnienia bezpieczeństwa obrotu owego rzeczywistego stanu prawnego nieruchomości poprzez dokonanie wpisu usuwającego niezgodność, zaś w przypadku powództwa z art. 189 k.p.c. jest to ustalenie, że dane prawo lub stosunek prawny, co do którego istnieje spór między stronami, istnieje lub nie istnieje. Sfera prawna chroniona przez orzeczenie jest więc w obu tych przypadkach zgoła odmienna, a przynajmniej nie tożsama, co wynika z samego już tylko odmiennego sformułowania sentencji rozstrzygnięcia uwzględniającego żądanie. $\mathrm{W}$ przypadku bowiem powództwa $\mathrm{z}$ art. 10 u.k.w.h. powinno to być zgodnie $z$ literalnym brzmieniem tego przepisu i przewidzianą w nim treścią żądania (ust. 1) czy też roszczenia (ust. 2) o usunięcie niezgodności ${ }^{35}$ - orzeczenie usuwające niezgodność poprzez stosowne ustalenie treści prawa lub stosunku prawnego podlegającego ujawnieniu w księdze wieczystej i zgodnego z rzeczywistym stanem prawnym nieruchomości aktualnym na dzień orzekania ${ }^{36}$, zaś w przypadku powództwa $\mathrm{z}$ art.

35 Stąd też posługiwanie się w niniejszej pracy sformułowaniem „powództwo o uzgodnienie” jest jedynie uproszczeniem przyjętym na potrzeby zachowania płynności wypowiedzi.

36 Szerzej na temat formuły rozstrzygnięcia por. uzasadnienie uchwały SN z 15 marca 2006 r., III CZP 106/05, «OSNC» 10/2006, poz. 160. Spośród trzech możliwych 
189 k.p.c. - jest to wyrok, w którym sąd ustala istnienie lub nieistnienie spornego pomiędzy stronami procesu prawa lub stosunku prawnego bez jakiegokolwiek odniesienia do treści księgi wieczystej. Zauważyć należy ponadto, że roszczenia w ramach każdej z wymienionych podstaw ukierunkowane są każdorazowo na inny aspekt rzeczywistości prawnej dotykającej powoda. Jeżeli bowiem powód formułuje żądania, z których każde zmierza do udzielenia mu ochrony - choćby w ramach tej samej sfery prawnej, ale w inny sposób, trudno wówczas mówić o zbiegu roszczeń, zwłaszcza gdy wyznacznikiem tego rodzaju kwalifikacji prawnej ma być zdolność do zaspokojenia w całości tego samego interesu powoda. Innymi słowy, treść żądania, tj. zawartego w pozwie wniosku o udzielenie ochrony prawnej, jako element wskazujący każdorazowo na konkretny wycinek sfery prawnej mający być objęty sądową ingerencją, a tym samym identyfikujący roszczenie procesowe, stanowi jeden z kluczowych wskaźników tożsamości tego roszczenia. Jeżeli więc każde z powództw, do których nawiązywał Sąd Najwyższy, dotyczy - w tej uznanej za wyjątkową sytuacji - sfery stosunków prawnorzeczowych, ale chroni inny wycinek tej sfery (wieczystoksięgowy, tj. prowadzący do uzgodnienia treści księgi wieczystej z rzeczywistym stanem prawnym ${ }^{37}$, a więc oddziałujący erga omnes i chroniący powoda w relacjach ze wszystkimi uczestnikami obrotu - w przypadku powództwa o usunięcie niezgodności, zaś w przypadku powództwa o ustalenie - fragment obejmujący stosunki inter partes obarczone niepewnością wynikającą ze sporu pomiędzy stronami procesu, a wiec chroniący sytuację powoda poprzez jej jednoznaczne określenie w relacji do sytuacji pozwanego ${ }^{38}$ ), o czym świadczy także choćby odmienny sposób udzielenia ochrony

rozstrzygnięć SN wykluczył opcję wyroku zawierającego skierowany do sądu wieczystoksięgowego nakaz usunięcia niezgodności poprzez dokonanie korekty wpisu, jak i wyroku zastępującego oświadczenie woli określonej osoby (tak na istotę ochrony prawnej udzielanej w procesie „o uzgodnienie” zapatrują się np. A. Szpunar, Roszczenie o uzgodnienie treści księgi wieczystej z rzeczywistym stanem prawnym, «Rejent» 7.12/1997, s. 14, i S. RUDNICKI, Komentarz do ustawy o ksiegach wieczystych i hipotece ${ }^{2}$, Warszawa 1996, s. 52).

37 Ten skutek prawny A. Szpunar (op. cit., s. 11) określa jako „dalej idący”.

38 Wyroki SN z 4 marca 2011 r., I CSK 340/10, «Lex» nr 785271, i z 14 lipca 2017 r., II CSK 745/16, «OSNC» 4/2018, poz. 43. Por. także P. Biernacki, Szczególne metody 
prawnej w wyroku, to zbyt upraszczające zdaje się twierdzenie o możliwości zaspokojenia w całości tego samego interesu powoda przez którekolwiek z tych powództw. Abstrahując od konsekwencji procesowych przyjęcia kwalifikacji „zbiegu” powództw (jako form ochrony sądowej konkurujących ze sobą o udzielenie ochrony zaspokajającej w całości interes prawny powoda), należy skonkludować, że odmienna treść żądanej ochrony prawnej nie pozwala na przyjęcie tego - nota bene dość mylącego - określenia sugerującego po głębszej analizie, że żądania ukierunkowane na uzyskanie innej treściowo ochrony prawnej zaspokajają w całości ten sam interes powoda. Prowadziłoby to do zdeprecjonowania znaczenia żądania jako elementu struktury roszczenia procesowego i oderwania interesu powoda rozumianego jako potrzeba uzyskania ochrony prawnej od treści tego żądania, tj. charakteru i sposobu udzielenia tej ochrony.

Tymczasem żądanie udzielenia określonej co do rodzaju ochrony prawnej, obejmujące wskazanie przedmiotu i sposobu tej ochrony ${ }^{39}$ (a więc i przedmiotu rozstrzygnięcia ${ }^{40}$ ), odgrywa kluczową rolę w kształtowaniu i identyfikowaniu roszczenia procesowego, wpływającą między innymi na ocenę dopuszczalności drogi sądowej, jurysdykcji i właściwości sądu, tryb postępowania, zakres kognicji sądu związanego treścią i podstawą faktyczną żądania pozwu, granice zawisłości sporu, a wreszcie powagi rzeczy osądzonej. Należna powodowi - wedle jego twierdzenia - ochrona prawna, której udzieleniu postępowanie ma służyć, stanowi więc oś, wokół której obraca się całe postępowanie ${ }^{41}$.

uzgodnienia treści księgi wieczystej z rzeczywistym stanem prawnym, «Przegląd Sądowy» 3/2018, s. 67.

39 Co do znaczenia woli powoda, a nie samego tylko sformułowania żądania w ramach jego wykładni - por. szerzej np. K. WeITz, Związanie sądu granicami $\dot{z} a-$ dania w procesie cywilnym, [w:] 'Aurea Praxis. Aurea Theoria'. Ksiega pamiatkowa ku czci Profesora Tadeusza Erecińskiego, I, red. J. Gudowski, K. Weitz, Warszawa 2011, s. 708-712.

40 Już w procesie rzymskim o granicach rozstrzygnięcia decydowało sformułowanie sporu dokonane w litis contestatio.

${ }^{41}$ W całym zresztą systemie prawa ochrona interesów danego podmiotu, a więc jego sfery prawnej uznawana jest za istotę (F. Liszt) i cel (R. von Ihering) prawa. Cyt. za: 
Z tych względów żądanie trafnie uznaje się za wyznacznik ${ }^{42}$ czy też "główny element" przedmiotu sporu ${ }^{43}$. Żądanie to jest procesowym wyrazem skorzystania przez powoda $z$ uprawnienia do dysponowania (rozporządzania) własnymi prawami i kształtowania swojej sytuacji prawnej, a innymi słowy „procesowym przejawem zasady autonomii woli stron"44. Przejawem tej zasady jest w szczególności swoboda rozporządzania przez stronę (Verfügungsfreiheit) jej uprawnieniem do wszczęcia postępowania ${ }^{45}$, czego nikt nie może jej zakazać ani nakazać - czy to przez przymuszenie do zgłoszenia lub popierania żądania, czy też przez wystąpienie z żądaniem w zamian uprawnionego. Sąd jest związany treścią żądania, co nie tylko oznacza, że nie może orzekać co do przedmiotu, który nie był objęty tym żądaniem (aliud), ani też zasądzać ponad żądanie (super) ${ }^{46}$, ale i obowiązany jest uwzględnić swobodę dysponowania przez powoda przedmiotem sporu (die Parteien Verfügungsfreiheit über den Streitgegenstand), tj. decydowania o rodzaju, treści i zakresie ochrony prawnej stanowiącej zasadniczy, fundamentalny wręcz łącznik między prawem materialnym i procesowym. Jest ona bowiem celem, na który ukierunkowane jest całe postępowanie, zdolnym do zaspokojenia i urzeczywistnienia potrzeby prawnej wyrażającej się w uzyskaniu rozstrzygnięcia co do istoty sprawy o żądanej treści ${ }^{47}$.

J. ZAJKowski, Wstęp do badań nad pojęciem interesu $w$ prawie $i$ w procesie cywilnym, Wilno 1935, s. 78-81.

42 „Der Antrag Bestimmungsfaktor der Streitgegenstandes ist” - tak W. ZeIss, K. SCHreiber, Zivilprozessrecht, Tübingen 2003, s. 129.

43 K. WeitZ, op. cit., s. 707.

44 R. Flejszar, Zasada dyspozycyjności w procesie cywilnym, Warszawa 2016, s. 207. Podobnie K. WeItz, op. cit., s. 679-680.

45 Por. L. Rosenberg, K.H. Schwab, P. Gottwald, Ziviprozessrecht, München 2010, s. 395-396.

${ }^{46} \mathrm{~W} \$ 308$ ust. $2 \mathrm{ZPO}$ niem. obie te sytuacje objęto jednym stwierdzeniem zakazującym sądowi przyznanie stronie czegoś, co nie było żądane (Das Gericht ist nicht befugt, einer Partei etwas zuzusprechen was nicht beanstragt ist).

47 W. Broniewicz, Przyczyny oddalenia powództwa..., s. 831; Idem, Warunki uwzględnienia powództwa, «PiP» 58.3/2003, s. 35. 
Potrzeba uzyskania ochrony prawnej (Rechtsschutzbedürfnis) ${ }^{48}$ objętej żądaniem pozwu, a więc jej znaczenie prawne dla powoda - pomimo braku wyraźnego normatywnego wyartykułowania w polskiej ustawie procesowej $^{49}$ - ujmowana jest w kategoriach przesłanki jurysdykcyjnej ${ }^{50}$ (ewentualnie - przesłanki udzielenia ochrony sądowej ${ }^{51}$, a w nauce prawa niemieckiego - przesłanki ochrony prawnej-Rechtsschutzvoraussetzun$g \mathrm{n}^{52}$ ) o szczególnym charakterze ${ }^{53}$, której brak skutkuje oddaleniem

48 Określana w nauce niemieckiej i austriackiej także jako Rechtsschutzinteresse (interes w uzyskaniu ochrony prawnej) czy np. im Rechte begründeten Interesses (uzasadniony prawnie interes). Por. B. Stephan, Das Rechtsschutzbedürfnis: Eine Gesamtdarstellung unter besonderer Berücksichtigung des Verfassungsprozesses, Berlin 1967, s. 5, 7-8; R. SPRUNG, Konkurrenz von Rechtsbehelfen im zivilgerichtlichen Verfahren, Wien-New York 1966, s. 46). Podczas gdy w nauce prawa niemieckiego potrzeba ochrony prawnej jest powszechnie wyodrębniana i traktowana w kategoriach ogólnej przesłanki procesowej warunkującej dopuszczalność postępowania, to już w prawie austriackim kwestia ta pozostaje dyskusyjna (por. szerzej P. RYLSKI, K. WeITZ, op. cit., s. 600 i 606 oraz przytoczona tam literatura).

49 W nauce prawa przekonująco wyjaśniono, że wyróżnieniu interesu prawnego jako generalnej przesłanki poszukiwania ochrony prawnej na drodze sądowej nie sprzeciwia się brak wyraźnej normy prawnej, bowiem istnienie takiego warunku może zostać odkodowane z zasad oraz całokształtu regulacji dotyczących systemu ochrony prawnej. Por. M. WAlasik, Poddanie się egzekucji aktem notarialnym, Warszawa 2008, s. 90; Ł. BŁAsZCZAK, op. cit., s. 40-41.

50 W. Broniewicz, Warunki uwzględnienia powództwa..., s. 35-36, 39; Idem, Przyczyny oddalenia powództwa..., s. 832; IDEM, Normy, przesłanki i zarzuty jurysdykcyjne w procesie cywilnym (przyczynek do zagadnienia stosunku prawa materialnego i prawa procesowego), «Studia Prawno-Ekonomiczne» 2/1969, s. 72.

51 M. Allerhand, Sądowe dochodzenie roszczeń niezupetnych, "Polski Proces Cywilny» 7-8/1939, s. 195-197; IDEm, Glosa do orzeczenia Sądu Najwyższego z 2.03.1937 r., C. II. 2512/36, «OSP» 1938, poz. 16, s. 20-21.

52 W. Brehm, [w:] Kommentar zur Zivilprozessordnung, eds. F. Stein, M. Jonas, I, Tübingen 2003, s. 99.

53 W. Broniewicz (Warunki uwzględnienia powództwa..., s. 38-39) sytuuje przesłanki jurysdykcyjne „między przesłankami procesowymi a przesłanką materialną”, argumentując, że nie warunkują one prawidłowości postępowania ani też nie wpływają na istnienie lub treść dochodzonego roszczenia (a więc nie dotyczą stosunku materialnoprawnego łączącego powoda z pozwanym), lecz uzasadniają „jedynie” potrzebę udzielenia ochrony prawnej powodowi. 
powództwa ${ }^{54}$. Potrzeba ta, jakkolwiek motywowana chęcią osiągnięcia określonej korzyści prawnej ${ }^{55}$, nie może być wszakże - jako kategoria o charakterze generalnym, właściwym każdej akcji procesowej - utożsamiana $\mathrm{z}$ interesem prawnym jako szczególną normatywną przesłanką powództwa o ustalenie. W znaczeniu ogólnym bowiem potrzeba uzyskania ochrony prawnej stanowi spiritus movens każdego twierdzenia powoda o naruszeniu lub zagrożeniu jego sfery prawnej ${ }^{56}$, bez względu na charakter powództwa, a tym samym genetycznie uzasadnia istnienie interesu prawnego ${ }^{57} \mathrm{w}$ domaganiu się sądowej ingerencji wyrażającej się w wydaniu określonej treści rozstrzygnięcia co do istoty sprawy ${ }^{58}$. Innymi słowy rozstrzygnięcie to jest powodowi (wnioskodawcy) potrzebne z tego względu, że „oddziaływa na stosunki, wśród których się on znajduje”; skoro zaś „odczuje on pomyślne lub niepomyślne zakończenie sprawy”, tym samym ma interes w jej wszczęciu ${ }^{59}$.

Tymczasem interes prawny jako szczególna przesłanka ustawowa wymieniona w art. 189 k.p.c., warunkująca rozstrzygnięcie w kwestii ustalenia istnienia lub nieistnienia prawa lub stosunku prawnego, ma swoje odmienne, ugruntowane już znaczenie zarówno w polskiej literaturze,

54 W. Broniewicz, Warunki uwzględnienia powództwa..., s. 35-36, 40.

55 Por. szerzej T. Row Iński, Interes prawny w procesie cywilnym i w postępowaniu nieprocesowym, Warszawa 1971, s. 12-18.

56 Tak też Ł. B£Aszczak, op. cit., s. 63. Autor słusznie też zauważa, że upraszczające i nieznaczące dla nauki prawa procesowego byłoby wywodzenie, że interes jest jedynie refleksem zasadności powództwa.

$57 \quad \mathrm{Na}$ powiązanie interesu prawnego z celem prawa do ochrony wskazywał już J. ZАJкоWsкi, op. cit., s. 78-79. W późniejszej literaturze podobnie argumentował W. SIEDLECKI, Istota procesu cywilnego z punktu widzenia interesów państwa i jednostki, «PiP» 2.7-8/1947, s. 51 .

58 W. WerhaNOWSKi, Zmiana skargi w austriackim procesie cywilnym, Lwów 1911, s. 26. Ten sam autor $\mathrm{w}$ innym opracowaniu (Znaczenie interesu prawnego $w$ procesie cywilnym, Lwów 1908, s. 1) stwierdza, że „interes prawny [...] ma ogólne znaczenie w procesie; jest podstawą każdego procesu i warunkiem użyczenia ochrony prawnej w formie każdego rodzaju wyroków; ma on zasadnicze znaczenie, a podniesiony do warunków skargi, staje się przyczyną odmówienia żądaniu skargi, gdy go nie ma względnie gdy wykazanym być w procesie nie może” (s. 22).

59 Tak obrazowo pojęcie interesu jako kategorii ogólnej wyjaśniał W. WERHANowski, Znaczenie interesu prawnego..., s. 5. 
jak i w orzecznictwie. Chociaż charakter prawny tej przesłanki był pierwotnie bardzo kontrowersyjny ${ }^{60}$, a i współcześnie w polskim prawie procesowym spór w tej kwestii - jak się wydaje - ponownie odżył ${ }^{11}$ (po okresie względnej powszechności poglądu kwalifikującego ją w kategoriach warunku merytorycznej zasadności żądania decydującego o jego uwzględnieniu bądź oddaleniu) ${ }^{62}$, to jednak nie budzi wątpliwości przynajmniej to, że na gruncie art. 189 k.p.c. interes prawny jest przesłanką o odrębnym znaczeniu, ściśle związanym z subsydiarnością żądania ustalenia stosunku prawnego lub prawa jako samodzielnego roszczenia. Panuje przy tym pełna zgoda co do tego, że subsydiarność

60 Por. szerzej K. Weitz, Charakter interesu prawnego jako przesłanki powództwa o ustalenie (art. 189 k.p.c.), [w:] 'Sine ira et studio'. Ksiega jubileuszowa dedykowana Sędziemu Jackowi Gudowskiemu, red. T. Ereciński, P. Grzegorczyk, K. Weitz, Warszawa 2016, s. 659-664.

${ }_{61}$ Za sprawą poglądu głoszącego, że interes prawny powoda przy powództwie o ustalenie jest przesłanką procesową, której brak uzasadnia odrzucenie pozwu na podstawie ogólnej analogii z art. $199 \$ 1$ k.p.c. Por. K. Weitz, Charakter interesu prawnego..., s. 666-682; IDEM, Charakter interesu prawnego jako przesłanki powództwa o ustalenie (art. 189 k.p.c.), «Przegląd Sądowy» 7-8/2018, s. 23, 28.

${ }_{62}$ Por. z wielu np. M. Waligórski, Polskie prawo procesowe cywilne w świetle zasady dyspozycji, «Studia Cywilistyczne» 2/1963, s. 29 i 34-36; S. WєорукA, Interes prawny jako przesłanka dopuszczalności zaskarżenia orzeczeń w procesie cywilnym, «Nowe Prawo» 9/1963, s. 937; W. Broniewicz, Przyczyny oddalenia powództwa, «PiP» 58.5-6/1964, s. 837; W. SIEDLECKI, Zarys postępowania cywilnego, Warszawa 1968, s. 149; T. RowIŃsKI, Interes prawny $w$ procesie cywilnym $i$ w postępowaniu nieprocesowym, Warszawa 1971, s. 29 i 79; M. SAWCZUK, Wznowienie postępowania cywilnego, Warszawa 1970, s. 105; K. PIASECKI, Wyrok pierwszej instancji w procesie cywilnym, Warszawa 1981, s. 149; E. WARzocha, Ustalenie stosunku prawnego lub prawa w sadowym postępowaniu cywilnym, Warszawa 1982, s. 43-45 i 53; W. Broniewicz, Warunki..., s. 35-36; M. RomańsKa, Wykorzystanie powództwa o ustalenie (art. 189 k.p.c.) w stosunkach umownych, «Palestra» 60.5-6/2015, s. 95-96; J. KuropatwiŃski, op. cit., s. 119. W najnowszym orzecznictwie por. m.in. orzeczenia SN z 7 czerwca 2017 r., I PK 212/16, «Lex» nr 2375936, a także wyroki SA w Warszawie z 7 czerwca 2018 r., V ACa 465/17, «Lex» nr 2524897, i z 25 kwietnia 2018 r., VII AGa 258/2018, «Lex» nr 2538281, oraz wyrok SA w Katowicach z 23 maja 2018 r., V AGa 28/2018, «Lex» nr 2505746. Wcześniejsze judykaty prezentujące taki pogląd wymienia K. Weitz, Charakter interesu prawnego jako przesłanki powództwa o ustalenie (art. 189 k.p.c.), «Przegląd Sądowy» 4/2018, s. 16-17, przyp. 66-70. 
samodzielnego powództwa o ustalenie oznacza jego ostateczność, tj. brak możliwości poszukiwania zaspokojenia interesu prawnego powoda (uzyskania ochrony prawnej przed możliwymi naruszeniami albo nawet już wobec dokonanych naruszeń) w jakikolwiek inny prawnie dopuszczalny sposób ${ }^{63}$. Warunek ten uznaje się co do zasady za spełniony, gdy powód nie ma żadnego innego narzędzia prawnego zapewniającego należytą ochronę jego interesów w danym momencie (a więc nie może skutecznie wytoczyć powództwa „dalej idącego”, tj. powództwa o zasądzenie świadczenia lub o ukształtowanie) ${ }^{64}$, na przykład z uwagi na niewymagalność (przedwczesność) roszczenia majątkowego lub dla odmiany - jego przedawnienie ${ }^{65}$, albo też sprzeczność roszczenia o zapłatę z zasadami współżycia społecznego, brak możliwości sprecyzowania żądania zasądzenia w zakresie, w jakim powód domaga się ustalenia ${ }^{66}$, czy brak znaczenia prawnego dla powoda powstałego

63 Uchwała SN z 30 grudnia 1968 r., III CZP 103/68, «OSNC» 5/1969, poz. 85; wyrok SN z 6 października 2017 r., V CSK 52/17, «Lex» nr 2372279; wyrok SN z 9 lutego 2012 r., III CSK 181/11, «OSNC» 7-8/2012, poz. 101 (w którym przyjęto, że interes prawny w rozumieniu art. 189 k.p.c. może być usprawiedliwiony także potrzebą uzyskania odpowiedniej ochrony prawnej w oznaczonym przez powoda okresie (np. w toku określonego postępowania upadłościowego), jeżeli powództwo przewidziane w tym przepisie stanowi jedyny środek ochrony takich praw.

64 E. Warzocha, op. cit., s. 20.

65 Np. gdy żądanie zasądzenia - wobec zarzutu przedawnienia - nie może być co do zasady uwzględnione, jednak pozwany wyraża gotowość spełnienia świadczenia, uzależniając ją od sądowego ustalenia. Por. J. Mokry, $W$ kwestii przedmiotu samodzielnych żądań ustalajacych $w$ sq̨dowym postępowaniu cywilnym, [w:] Studia z procesu cywilnego, red. K. Korzan, Katowice 1986, s. 146.

66 Co pozwala - jak się powszechnie przyjmuje - na ustalenie poszczególnych tylko samodzielnych elementów stosunku prawnego, w tym dotyczących istnienia i ważności jego źródła (np. w razie wątpliwości co do ważności umowy), podmiotów tego stosunku (np. w razie sporu co do ważności i skuteczności przejęcia długu lub przystąpienia do długu), jego treści (w tym zarówno wierzytelności i długu, jak i składających się na nie poszczególnych uprawnień i obowiązków), czy także przedmiotu świadczenia. Por. J. Korzonek, Przyczynki do polskiego procesu cywilnego, Kraków 1931, s. 220; E. Warzocha, op. cit., s. 76-77; E. WEngerek, Powództwo o ustalenie, «RPEiS» 21.1/1959, s. 18-19; J. Mokry, op. cit., s. 142-143. Inna rzecz, że ustalenie niektórych tylko składników stosunku prawnego (poszczególnych praw z niego wynikających) w sytuacji, gdy możliwe jest już dochodzenie roszczenia o zasądzenie świadczenia wynikającego 
ewentualnie w przyszłości roszczenia o zasądzenie wobec zagrożenia przedawnieniem. Nawet gdyby przyjąć, że przewidziana w art. 189 k.p.c. przesłanka w postaci interesu prawnego jest szczególnym przejawem potrzeby ochrony prawnej ${ }^{67}$ determinującej przecież - jak wskazano we wcześniejszych rozważaniach - podjęcie każdej akcji procesowej, to z pewnością stwierdzenie, że inne żądanie jest w stanie realizować ten sam interes prawny powoda, który uzasadniałby wytoczenie powództwa o ustalenie, stanowi nie tylko nieuprawnione uproszczenie całej obszernej problematyki interesu prawnego w ustaleniu, lecz także pozostaje w sprzeczności z logicznymi założeniami tej instytucji. O istnieniu interesu prawnego w ustaleniu można bowiem mówić właśnie wtedy, gdy powodowi obiektywnie nie przysługuje żadne inne skuteczne narzędzie prawne, w tym również roszczenie procesowe, pozwalające zaspokoić jego potrzebę prawną.

Niezależnie od powyższego zauważyć należy, że potrzeba uzyskania ochrony prawnej oddziałującej we wszystkich wymienionych powyżej aspektach determinuje w sposób odmienny cel każdego z powództw wymienionych w art. 10 u.k.w.h. i art. 189 k.p.c. i sprowadza się w przypadku pierwszego z nich do uzyskania zmian w treści księgi wieczystej oddziałujących względem wszystkich, zaś w przypadku drugiego - do uzyskania pewności w zakresie określonych stosunków cywilnoprawnych pomiędzy stronami sporu. Twierdzenie więc Sądu Najwyższego, że wymienione powództwa mogą zaspokajać ten sam interes prawny, jest podwójnie nieuprawnione. Przede wszystkim z tego względu, że upraszczające jest utożsamianie wyżej wymienionych celów obu powództw, ale i dlatego, że brak jest jednoznaczności w posłużeniu się pojęciem interesu

z tego stosunku w praktyce występuje najczęściej w celu ustalenia odpowiedzialności pozwanego za skutki zdarzenia mogące ujawnić się w przyszłości (por. uchwałę SN z 24 lutego 2009 r., III CZP 2/09, «OSNC» 12/2009, poz. 168).

67 Por. szerzej K. Weitz, Charakter interesu prawnego jako przesłanki powództwa o ustalenie (art. 189 k.p.c.), «Przegląd Sądowy» 7-8/2018, s. 11-15; Ł. BŁAszCzAK, op. cit., s. 41. Tak też SN w uzasadnieniu wyroku z 24 kwietnia 2015r., II CSK 438/14, «Lex» nr 1710353. Na marginesie zauważyć należy, że konsekwencje przyjęcia tej tezy powinny być uwzględnione także w ramach analizy skutków procesowych braku interesu prawnego. 
prawnego, który stanowi szczególną, normatywną przesłankę powództwa o ustalenie, podczas gdy w przypadku powództwa z art. 10 u.k.w.h. tak rozumiana przesłanka normatywna nie istnieje, a mówić można tu jedynie o potrzebie ochrony prawnej jako kategorii ogólnej. Określanie więc w odniesieniu do powództwa $\mathrm{z}$ art. 10 u.k.w.h. tej nienormatywnej wprawdzie, ale wynikającej z istoty postępowania sądowego, figury mianem interesu prawnego nie jest uzasadnione, bowiem - inaczej niż w przypadku powództwa o ustalenie - nie jest ona samodzielną przesłanką żądania ocenianą in principio i warunkującą potrzebę badania wszelkich pozostałych warunków zasadności roszczenia procesowego, lecz jest emanacją bezzasadności (lub niedopuszczalności) powództwa (ewentualnie braku legitymacji procesowej), niepodlegającą oddzielnemu badaniu i ujawniającą się w wyniku sprawy.

5. Procesowe KONSEKWENCJE OdRĘBNOŚCI TREŚCI I CELÓW POWÓDZTW Z ART. 10 U.K.W.H. I ART. 189 K.P.C.

Z procesowego punktu widzenia analizowana sytuacja, a więc potrzeba uzyskania zarówno skutków prawnorzeczowych w wymiarze wieczystoksięgowym, jak i innych skutków cywilnoprawnych (zwłaszcza gdy przesądzenie tych ostatnich nie może stanowić bezpośrednio podstawy wpisu w księdze wieczystej) może uzasadniać połączenie obu analizowanych powództw w jednym postępowaniu. Możliwość ta - zapewne $z$ uwagi na rzadkie zastosowanie w praktyce - nie jest przedmiotem rozważań zarówno w orzecznictwie, jak i w literaturze przedmiotu. Tymczasem, uwzględniając niejednolitość orzecznictwa i antycypując wątpliwości sądu co do oceny przesłanki interesu prawnego w ustaleniu, jak również wówczas, gdy poza uzyskaniem korekty treści księgi wieczystej powód dąży do przesądzenia innych jeszcze kwestii prawnych wymagających sądowej oceny, może dojść do połączenia obu roszczeń procesowych w jednym pozwie i to zarówno na zasadzie kumulacji „łącznej”, kiedy powód żąda uzgodnienia i równoczesnego ustalenia 
dalszych skutków cywilnoprawnych ${ }^{68}$, jak i kumulacji opartej z reguły na relacji ewentualności, gdy w ocenie powoda każde $z$ analizowanych powództw - choć w jakościowo różniący się sposób - może zaspokoić jego potrzebę uzyskania ochrony prawnej. Druga spośród wymienionych zależności może być - jak się na pierwszy rzut oka wydaje - uzasadniana tożsamością zamierzonej ochrony prawnej wyrażającej się na przykład w przesądzeniu, że powód pozostaje właścicielem nieruchomości lub jest uprawniony z tytułu hipoteki korzystającej z pierwszeństwa zaspokojenia. Zarówno bowiem ustalenie istnienia prawa własności powoda (lub istnienia i pierwszeństwa przysługującej mu hipoteki) na podstawie art. 189 k.p.c., jak i uzgodnienie treści księgi wieczystej na jego korzyść w trybie art. 10 u.k.w.h. będzie w stanie w pewnym aspekcie zadośćuczynić potrzebie przesądzenia tego, komu przysługuje prawo rzeczowe. W takim jednak wypadku przyjęty kierunek interpretacyjny przesłanki interesu prawnego w ustaleniu (jako kategorii odmiennej od wspomnianej wcześniej potrzeby uzyskania ochrony prawnej towarzyszącej każdemu roszczeniu procesowemu i znajdującej wyraz w charakterze czy rodzaju żądanej ochrony) będzie z reguły przemawiał za oddaleniem powództwa wytoczonego na podstawie art. 189 k.p.c. ${ }^{69} \mathrm{z}$ uwagi na możliwość skorzystania z innej drogi ochrony prawnej, a więc powództwa

68 Taki przypadek zaistniał właśnie w stanie faktycznym sprawy, w której zapadł wyrok SN z 23 marca 2018 r., skoro - jak uzasadniał SN - w analizowanym przypadku interes prawny powoda nie sprowadzał się jedynie do usunięcia skutków ujawnienia pozwanej, jako właściciela nieruchomości w księgach wieczystych, lecz dotyczył też dalszych rozliczeń między stronami w ramach podziału majątku. Gdyby więc w konkretnej sprawie orzeczenie ustalające - z uwagi na swą treść - nie mogło stanowić podstawy wpisu, gdyż nie dotyczyłoby bezpośrednio zdarzenia, które stanowiło materialnoprawną podstawę wpisu lub wymagało uwzględnienia innych jeszcze, prawnie doniosłych okoliczności wykraczających poza te, które może badać sąd wieczystoksięgowy, wówczas możliwa do pomyślenia byłaby kumulacja powództwa $\mathrm{z}$ art. 10 u.k.w.h. i powództwa $z$ art. 189 k.p.c. ustalającego dalsze skutki cywilnoprawne. Taka kumulacja nie byłaby zresztą wykluczona $z$ uwagi na samą tylko obawę powoda co do restrykcyjnego podejścia sądu wieczystoksięgowego do problematyki podstaw wpisu (w tym obawę przed odmową wpisu na podstawie samego tylko wyroku ustalającego).

69 Względnie - za jego odrzuceniem, jeśli przyjąć koncepcję zakładającą, że interes prawny jest procesową przesłanką powództwa z art. 189 k.p.c. 
z art. 10 u.k.w.h. Taka argumentacja jest o tyle godna podtrzymania, że wyznacza stosunkowo przejrzyste kryterium dochodzenia ustalenia prawa lub stosunku prawnego dotyczącego nieruchomości mającej urządzoną księgę wieczystą w trybie art. 189 k.p.c., a mianowicie pozwala aprobować przekonanie o istnieniu interesu prawnego $\mathrm{w}$ rozumieniu przyjętym w tym ostatnim przepisie wówczas, gdy poza korektą treści księgi wieczystej powód dąży do przesądzenia innych jeszcze skutków prawnych, albo też gdy nie zmierza do usunięcia niezgodności w treści księgi wieczystej (np. ze względu na brak takiej niezgodności), lecz do przesądzenia o istnieniu lub nieistnieniu prawa lub stosunku prawnego dotyczącego nieruchomości mającej urządzoną księgę wieczystą, którego kwestionowanie zagraża lub narusza (czy też w przyszłości może zagrozić lub naruszyć) inną sferę prawną powoda.

O ile teoretycznej przynajmniej możliwości połączenia obu powództw (roszczeń procesowych) w jednym postępowaniu nie przeczy cytowana powyżej teza wyroku Sądu Najwyższego, który przyjął przecież wyraźnie istnienie mnogości powództw, o tyle jednak trudno zaakceptować, a z pewnością trudno wskazać konsekwencje procesowe stanowiska, że w takim wypadku zachodzi ich zbieg. Skoro bowiem oba powództwa w tych wyjątkowych sytuacjach miałyby konkurować ze sobą o to, które ma zaspokoić taki sam interes prawny powoda, pojawiłby się problem właściwego określenia przez powoda ich wzajemnej relacji procesowej $\mathrm{w}$ razie chęci ich połączenia $\mathrm{w}$ jednym postępowaniu. Tymczasem potrzeba prawna, jaką zaspokajać ma każde $\mathrm{z}$ analizowanych powództw, a konkretnie odmienność celów i skutków prawnych, odznacza się daleko idącą odrębnością wykluczającą twierdzenie o tożsamości interesu prawnego. Sam Sąd Najwyższy skonstatował zresztą - w oparciu o własne dotychczasowe orzecznictwo - że „powództwa z art. 189 k.p.c. i art. 10 u.k.w.h. realizują odrębne kategorie roszczeń procesowych, stanowiące dwa niezależne środki ochrony prawnej, oparte na różnych przesłankach i zmierzające do osiągnięcia odmiennego celu. Powództwo z art. 10 u.k.w.h. służy uzgodnieniu treści księgi wieczystej z rzeczywistym stanem prawnym aktualnym na dzień orzekania. Zmierza do zaspokojenia roszczenia typu rzeczowego i pozostaje w ścisłym związku z ustrojową funkcją ksiąg wieczystych. Jest zatem właściwym instrumentem do 
rozstrzygnięcia sporu, której ze stron przysługuje prawo do nieruchomości objętej księgą wieczystą”. Z kolei powództwo oparte na art. 189 k.p.c. służy udzieleniu ochrony w zakresie innych skutków prawnych mogących wyniknąć ze stosunku, który powód kwestionuje i które może usunąć wyrok ex tunc. Jakkolwiek więc w konkretnym stanie faktycznym różnice pomiędzy nimi, a zwłaszcza zamierzonymi skutkami prawnymi mogą być subtelne, a nawet niedostrzegalne lub nierelewantne dla samego powoda, to jednak nie pozwalają one zarówno na konstatację zakładającą tożsamość ochrony prawnej, jak i przekonanie o zachodzącym zbiegu roszczeń.

KonKuRENCYjNość POWÓDZTW Z ART. 189 K.P.C. I ART. 10 U.K.W.H. (UWAGI NA TLE WYROKU SĄDU NAJWYŻSZEGo

Z 23 MARCA 2018 R.)

\section{Streszczenie}

W artykule poruszona została kwestia relacji pomiędzy powództwem o usunięcie niezgodności między treścią księgi wieczystej a rzeczywistym stanem prawnym, znajdującym podstawę normatywną w art. 10 u.k.w.h., i powództwem $\mathrm{z}$ art. 189 k.p.c. o ustalenie istnienia lub nieistnienia prawa lub stosunku prawnego. Autorka aprobująco odnosi się do poglądu akcentującego odmienność celów i charakteru obu tych powództw jako zmierzających do osiągnięcia innego rodzaju ochrony prawnej. Weryfikacja tego założenia pozwala także na zaaprobowanie tezy, że interesu prawnego w wytoczeniu powództwa o ustalenie na podstawie art. 189 k.p.c. nie wyklucza możliwość zgłoszenia przez powoda roszczenia $z$ art. 10 u.k.w.h.

W ocenie autorki powyższe stanowisko nie uzasadnia jednak posługiwania się na gruncie prawa procesowego cywilnego pojęciem „zbieg roszczeń w zakresie ww. powództw” i to zarówno z przyczyn metodologicznych, jak i normatywnych. Z perspektywy wspomnianej odmienności form ochrony prawnej i sfery, w zakresie której ta ochrona ma oddziaływać, nieuprawnione jest twierdzenie, że powództwa $\mathrm{z}$ art. 10 u.k.w.h. i art. 189 k.p.c. są w stanie zaspokoić ten sam interes prawny. 
Competitiveness of Actions under ARt. 189 of the Polish Code of Civil Procedure and art. 10 of the Polish Land and Mortgage Register Act: Remarks on the Verdict of 23 March 2018 Issued by the Supreme Court

\section{Summary}

This article considers the relationship between an action for the removal of inconsistencies between an entry in the Polish land and mortgage register and the actual legal status of the property in question. The grounds for action to amend an entry in the register are given in Art. 10 of Ustawa o ksiegach wieczystych i hipotece (the Land and Mortgage Register Act); and the grounds to determine whether a claimant has a right or legal relationship (justifying such an amendment) are defined under Art. 189 of the Code of Civil Procedure. The author agrees with the view which says that the nature of these two actions is different, and that they have different aims, intended to achieve different types of legal protection. If this assumption holds, it will also show that a claimant's legal interest in bringing an action pursuant to art. 189 of the Code of Civil Procedure does not rule out his option to bring a claim under Art. 10 of the Land and Mortgage Register Act as well.

However this position does not justify the use of the concept of "concurrence of claims" within civil procedural law, either for methodological or normative reasons. From the perspective of the different forms of legal protection offered by these two types of claim and the scope of their effects, it would be inadmissible to allege that claims under Art. 10 of the Land and Mortgage Register Act and under Art. 189 of the Code of Civil Procedure meet the same legal interest.

Słowa kluczowe: powództwo o ustalenie istnienia lub nieistnienia prawa lub stosunku prawnego; interes prawny; usunięcie niezgodności w księdze wieczystej; zbieg roszczeń.

Keywords: action to determine whether the claimant has a right or legal relationship; a claimant's legal interest; removal of inconsistencies in the land and mortgage register; concurrence of claims. 


\section{Bibliografia}

Allerhand M., Glosa do orzeczenia Sądu Najwyższego z 2.03.1937 r., C. II. 2512/36, «OSP» 1938, poz. 16, s. 20-21.

Allerhand M., Sąowe dochodzenie roszczeń niezupetnych, «Polski Proces Cywilny» 7-8/1939, s. 195-197.

Berutowicz W., Postepowanie cywilne w zarysie, Warszawa 1974.

BERUTOWICz W., Znaczenie prawne sądowego dochodzenia roszczeń, Warszawa 1966.

BIERNACKI P., Szczególne metody uzgodnienia treści księgi wieczystej z rzeczywistym stanem prawnym, «Przegląd Sądowy» 3/2018, s. 56-73.

BŁAszCZAK Ł., Znaczenie interesu prawnego w poszukiwaniu ochrony prawnej $w$ procesie cywilnym na przykładzie poszczególnych rodzajów powództw, [w:] 'Ius est a iustitia appellatum'. Księga jubileuszowa dedykowana Profesorowi Tadeuszowi Wiśniewskiemu, red. T. Ereciński, J. Gudowski, M. Pazdan, red. nauk. M. Tomalak, Warszawa 2017, s. 35-80.

BRONIEWICZ W., Normy, przesłanki i zarzuty jurysdykcyjne w procesie cywilnym (przyczynek do zagadnienia stosunku prawa materialnego i prawa procesowego), «Studia Prawno-Ekonomiczne» 2/1969, s. 63-78.

Broniewicz W., Przyczyny oddalenia powództwa, «PiP» 19.5-6/1964, s. 831-840.

Broniewicz W., Warunki uwzględnienia powództwa, «PiP» 58.3/2003, s. 32-41.

CARnelutti F., Sistema di diritto processuale civile, I: Funzione e composizione del processo, Padova 1936.

CieśLAK S., Powiązania wewnątrzsystemowe w postępowaniu cywilnym, Warszawa 2013.

CzAchóRski W., Zobowiązania. Zarys wykładu, Warszawa 1983.

Dobrzański B., Glosa do orzeczenia Sąu Najwyższego z dnia 9 lipca 1963 roku w sprawie o sygn. 3 PR 362/62, «OSPiKA»11/1964, poz. 219, s. 466.

FlejSzar R., Zasada dyspozycyjności w procesie cywilnym, Warszawa 2016.

GoŁĘBiowski K., O domniemaniach związanych $z$ wpisami w ksiegach wieczystych, ich obalaniu oraz konstytutywnym charakterze wpisu (część I), «Przegląd Sądowy» 10/2014, s. 78-93.

Grzybowski S., Prawo cywilne. Zarys części ogólnej, Warszawa 1985.

GrZYвowski S., SkĄPSKi J., WójCik S., Zarys prawa cywilnego, Warszawa 1988.

Korzan K., Orzeczenia konstytutywne w postępowaniu cywilnym, Warszawa 1972.

Korzonek J., Przyczynki do polskiego procesu cywilnego, Kraków 1931. 
Kuropatwiński J., Powództwo o uzgodnienie stanu prawnego ujawnionego w księdze wieczystej. Glosa do wyroku Sądu Najwyższego z dnia 9 lutego 2012 r. (III CSK 181/11), «Przegląd Sądowy» 1/2013, s. 114-124.

ŁĘTOWsKa E., Zbieg norm w prawie cywilnym, Warszawa 2002.

MOKRY J., W kwestii przedmiotu samodzielnych żądań ustalających w sadowym postępowaniu cywilnym, [w:] Studia z procesu cywilnego, red. K. Korzan, Katowice 1986, s. 131-155.

Monteleone G., Scritti sul processo civile, I: Teoria generale del processo Disposizioni generali, Roma 2012.

Mucha J., Zawisłość sprawy w procesie cywilnym, Warszawa 2014.

Ohanowicz A., Zbieg norm w polskim prawie cywilnym, [w:] Alfred Ohanowicz. Wybór prac, wstęp Z. RADWAŃski, oprac. A. GulCZYŃski, Warszawa 2007, s. 169-274.

Oleszko A., Wyrok sądowy jako podstawa wpisu do księgi wieczystej, «Przegląd Sądowy» 5/1993, s. 57-65.

PiASECKI K., Wyrok pierwszej instancji w procesie cywilnym, Warszawa 1981.

Podleś P., Uwagi na temat relacji pomiędzy postępowaniem wieczystoksięgowym i postępowaniem o usunięcie niezgodności między stanem prawnym nieruchomości ujawnionym $w$ księdze wieczystej a rzeczywistym stanem prawnym, «Przegląd Sądowy» 5/2011, s. 16-27.

RESICH Z., 'Res iudicata', Warszawa 1978.

Romańska M., Wykorzystanie powództwa o ustalenie (art. 189 k.p.c.) w stosunkach umownych, «Palestra» 60.5-6/2015, s. 94-109.

Rosenberg L., Schwa b K.H., Gottwald P., Ziviprozessrecht, München 2010.

RowiŃski T., Interes prawny $w$ procesie cywilnym $i$ w postępowaniu nieprocesowym, Warszawa 1971.

RUdnICKI S., Glosa do postanowienia SN z dnia 25 sierpnia 2011 r., II CSK 665/10, «OSP» 3/2012, poz. 31.

RUdNicki S., Komentarz do ustawy o ksiegach wieczystych i hipotece, 2, Warszawa 1996.

RudNicki S., Ustawa o ksiegach wieczystych i hipotece. Przepisy o postępowaniu w sprawach wieczystoksiegowych. Komentarz, Warszawa 2010.

Rylski P., Weitz K., Intérét, interesse ad impugnare, Beschwer, aggrievance, [w:] Oblicza prawa cywilnego. Ksiega jubileuszowa dedykowana Profesorowi Janowi Błeszyńskiemu, red. K. SzczePAnowsKa-KozŁowska, Warszawa 2013, s. 584-615.

SAwCzuk M., Wznowienie postępowania cywilnego, Warszawa 1970. 
SIEDLECKI W., Istota procesu cywilnego z punktu widzenia interesów państwa i jednostki, «PiP» 2.7-8/1947, s. 46-51.

SiedLECKi W., Zarys postępowania cywilnego, Warszawa 1968.

SŁUPIK J.D., Powództwo o ustalenie istnienia lub nieistnienia stosunku prawnego lub prawa (art. 189 k.p.c.) a powództwo o uzgodnienie treści księgi wieczystej z rzeczywistym stanem prawnym (art. 10 ust. 1 u.k.w.h.), «Rejent» 24.7/2014, S. 92-105.

SpRUNG R., Konkurrenz von Rechtsbehelfen im zivilgerichtlichen Verfahren, Wien-New York 1966.

Stephan B., Das Rechtsschutzbedürfnis: Eine Gesamtdarstellung unter besonderer Berücksichtigung des Verfassungsprozesses, Berlin 1967.

System prawa cywilnego, I: Część ogólna, red. nacz. W. CzACHóRsKi, red. tomu

S. GRzyвоwsкi, Wrocław-Warszawa-Kraków-Gdańsk-Łódź 1985.

System prawa cywilnego, II: Własność i inne prawa rzeczowe, red. J. IGNATOwicz, Wrocław 1977.

System prawa prywatnego. Prawo cywilne - część ogólna, I, red. M. SAfJAN, Warszawa 2012.

SzPunar A., Roszczenie o uzgodnienie treści księgi wieczystej z rzeczywistym stanem prawnym, «Rejent»7.12/1997, s. 9-22.

Trammer H., Następcza bezprzedmiotowość procesu cywilnego, Kraków 1950. WALASıK M., Poddanie się egzekucji aktem notarialnym, Warszawa 2008.

Waligórski M., Kumulacja roszczeń w procesie, «Polski Proces Cywilny» 18-19/1937, s. 545-561.

Waligórski M., Polskie prawo procesowe cywilne w świetle zasady dyspozycji, «Studia Cywilistyczne» 2/1963, s. 4-70.

WARzocha E., Ustalenie stosunku prawnego lub prawa w sadowym postępowaniu cywilnym, Warszawa 1982.

Waśkowski E., Powództwo i jego zmiana, «Polski Proces Cywilny» 3/1935, S. $65-72$.

WeITz K., Charakter interesu prawnego jako przesłanki powództwa o ustalenie (art. 189 k.p.c.), «Przegląd Sądowy» 7-8/2018, s. 7-36.

WeITz K., Charakter interesu prawnego jako przesłanki powództwa o ustalenie (art. 189 k.p.c.), [w:] 'Sine ira et studio'. Ksiega jubileuszowa dedykowana Sędziemu Jackowi Gudowskiemu, red. T. Ereciński, P. Grzegorczyк, K. Weitz, Warszawa 2016, s. 656-682.

WeItz K., Związanie sadu granicami żądania w procesie cywilnym, [w:] 'Aurea Praxis. Aurea Theoria'. Ksiega pamiątkowa ku czci Profesora Tadeusza Erecińskiego, I, red. J. Gudowski, K. Weitz, Warszawa 2011, s. 679-715. 
Wengerek E., Powództwo o ustalenie, «RPEiS» 21.1/1959, s. 1-33.

WERHANOWSKI W., Zmiana skargi w austriackim procesie cywilnym, Lwów 1911. WERHANOWSKI W., Znaczenie interesu prawnego w procesie cywilnym, Lwów 1908.

WŁODYKa S., Interes prawny jako przesłanka dopuszczalności zaskarżenia orzeczeń w procesie cywilnym, «Nowe Prawo» 9/1963, s. 937.

Zajkowski J., Wstęp do badań nad pojęciem interesu $w$ prawie $i w$ procesie cywilnym, Wilno 1935.

ZAwisZA A., Wyrok ustalający nieważność czynności prawnej jako podstawa wpisu w księdze wieczystej, «Rejent» 26.1/2016, s. 112-138.

Zeiss W., Schreiber K., Zivilprozessrecht, Tübingen 2003.

Ziembińsкi Z., Problematyka ogólna zbiegu przepisów prawnych, [w:] Studia z prawa zobowiązań, red. Z. RADWAŃski, Warszawa-Poznań 1979, s. 333-346. 